prepared in manuscript, but his enthusiasm was far greater than his strength and resources. With very few facilities for successful botanical work, and a weak physical constitution, he was compelled in discouragement to give up this large undertaking.

Dr. Joor's herbarium, which is the main record of his work, is not large, but is rich in specimens from the region where his life was spent. It is especially valuable because from that part of the south not well known to botanists, and covered by none of our manuals. A part of his collections, as before stated, were incorporated into the herbarium of Tulane University when he was connected with it. The rest were purchased from Mrs. Joor in 1897 by the Missouri Botanical Garden.

Most of the collections were made about New Orleans and Baton Rouge, Galveston bay, and other parts of Harris county, Texas, where he lived, and in Navarro and adjoining counties when he lived at Birdston, with occasional excursions into other parts of the south. In the last year of his life he spent several weeks along the Mississippi gulf coast, making large collections and preparing a list of the plants of that region. His herbarium was also enriched by the collections of botanical friends and others in whom his own devotion had inspired an interest in plants. Dr. Joor was a correspondent of Vasey, Engelmann, Mohr, Chapman, and other botanists of this country. He was the first collector of several new southern plants. Though he described none himself, his herbarium notes show that some afterward described by others were recognized by him as new. Among others of which he was the first discoverer, Panicum Joorii Vasey, Carex Joorii Bailey, Barbula Jooriana Müller, and Euphorbia corollata Joorii Norton, bear his name.-J. B. S. Norton, Missouri Botanical Garden.

\title{
FOUR GENERATIONS OF BOTANISTS IN ONE FAMILY.
}

IT is seldom that the names of more than one generation of a family appear in connection with any one branch of scientific research. The history of science appears to show that genius or ability is not handed down, at least to any remarkable degree, in most families from one generation to another. As a general thing the pursuit of science is not lucrative enough to keep more than one generation from becoming paupers, and even where there is some wealth and ability the suc- 
ceeding generation, as a rule, is not fortunate enough to inherit the characteristic traits necessary to follow the calling of its predecessors. However, exceptions occur where similar traits have shown themselves in a decided manner for more than one generation in a single family. Among these may be mentioned the Darwin and Schimper families, and the DeCandolle family offers one of the most striking illustrations. Indeed, the history of science scarcely shows another name representing so many illustrious and able workers in one family, devoting themselves to one branch of science.

It was my fortune to stop a few days at Geneva during the summer of 1896 , where I had the pleasure of spending some delightful and profitable hours with the DeCandolle family. The family is one of the oldest as well as one of the most highly esteemed in Geneva, having fled from Provençe to Geneva in the year 1591, where they have been held in esteem for many years as public spirited and highly accomplished citizens.

Augustin-Pyrame De Candolle is known to botanists as a rare genius, who accomplished a prodigious amount of work, and who left behind him a name second only to that of Linnæus. The charming traits which this renowned botanist is said to have possessed are known only to the younger generation of botanists through his memoirs. However, these traits are quite readily realized by those who have met the present members of the family.

It is not my intention to mention the various works of the elder DeCandolle or of those of his son Alphonse, as such an enumeration would be quite unnecessary.

The name of Casimir DeCandolle, the son of Alphonse, has also long been familiar to American botanists, but the name of his youngest son Augustin, who is now devoting his attention to botany, is probably not familiar on this side of the Atlantic.

M. Augustin DeCandolle, who now represents the fourth botanical generation in this family, and who bears the name of his illustrious great-grandfather, is about 27 or 28 years old, and was born and educated in England, which was formerly the home of his mother. He studied a number of years at Rugby, and after finishing his course there he spent a year at Heidelberg, going from there to the University of Leipzig, where he took a course in jurisprudence.

Although he did not take the university course in botany while at Leipzig, his interest in the subject was quite marked, and his oppor- 
tunities and associations were always such that he naturally acquired a considerable knowledge of this subject.

Since his return from Leipzig he has spent most of his time assisting his father at the herbarium in Geneva, besides carrying on some original work along histological lines, some of the results of which have already appeared as abstracts in the Archives des sciences physiques et naturelles, of Geneva.

M. Augustin DeCandolle occupies a villa pleasantly situated in the suburbs of Geneva, which also includes about sixty acres of land; while that of his father is on the shores of Lake Geneva, near Versoix, and about ten or twenty minutes' ride from Geneva. Both residences are provided with greenhouses and gardens.

One of the most interesting features connected with Geneva for a botanist, however, is the herbarium and library which is contained in the old DeCandolle homestead at Cour de St. Pierre, and which was formerly occupied by the elder DeCandolle. The building is situated in the older parts of the city, and is not far from the University and Botanical Gardens, which were laid out by the elder DeCandolle; and here is to be seen a very good life-size statue of its founder. The herbarium and library and working rooms occupy the upper stories, and, with the exception of the large number of cases which have been added, the rooms are just as they were when occupied for residence by the elder DeCandolle.

Here one can not only find interest in the large herbarium, but he will find the rarest and most valuable collection of old botanical books in existence. The library contains many other interesting features, such as photographs and autographs of nearly all the botanists the DeCandolles have known. It contains also all the prominent periodicals and recent botanical literature of various countries up to date. The expense of maintaining the herbarium and library is met entirely by the DeCandolles. It is the desire of M. Casimir DeCandolle to make the library as complete as possible, and he is always pleased to receive contributions from American botanists.

New plants are continually being added to the herbarium, which are placed in the general collection. The special collection relating to the Prodromus is kept by itself. As this work is of considerable consequence, an experienced curator is employed to look after it, together with the many details connected with the ever increasing library. 
It is here that Casimir DeCandolle and his son Augustin do their botanical work, and although the library and collection is a private one, the keeping up of which involves considerable expense, they are always willing to have other botanists avail themselves of any appointments which the large collection offers.

M. Casimir DeCandolle speaks English fluently, and his intense interest in all matters pertaining to botany, and his characteristic modesty, together with his exceedingly broad and comprehensive knowledge, afford a striking contrast to what one often meets in other parts of the continent. As in the case of the other DeCandolles, he has contributed to every department of botany. We find the name associated not only with an enormous amount of systematic investigation, but also with the physiology, histology, morphology and history of plants.G. E. Stone, Mass. Agric. College, Amherst.

\section{SOME RESULTS FROM THE STUDY OF ALLIUM.}

DURING the summer of 1897 , at the University of Chicago, I began a morphological investigation of certain species of Allium, being attracted chiefly by the often quoted polyembryony of $A$. tricoccum Ait. My results in the case of this species indicate that if polyembryony occurs at all, it is very rare. Besides $A$. tricoccum, I examined more or less thoroughly $A$. cernuum Roth, and $A$. Canadense Kalm, with the same general result. Seventy-five embryo-sacs of $A$. tricoccum were examined at the stage in which both egg apparatus and antipodal cells ought to have been found. The egg apparatus was found in seventy of them, and the appearance of the sacs in which it was not found would indicate that it had been lost by accident, as all other structures were normal. Of the seventy-five sacs, only sixteen contained antipodal cells, and these antipodal cells were usually small, and it was seldom that more than one or two could be found. In one sac there were three antipodal cells in a row, but in other cases where three were found they were crowded together irregularly. Wherever antipodal cells were found, they had a shriveled, dead appearance, and stained with difficulty or not at all. Twenty-six embryos were examined, all of which had developed from the egg cell. No trace of antipodal cells could be found in any sac in which the embryo had begun to develop. 


\section{$2 \mathrm{BHL}$ Biodiversity Heritage Library}

Stone, George E. 1898. "Four Generations of Botanists in One Family." Botanical gazette 26(4), 274-277. https://doi.org/10.1086/327743.

View This Item Online: https://www.biodiversitylibrary.org/item/94397

DOI: https://doi.org/10.1086/327743

Permalink: https://www.biodiversitylibrary.org/partpdf/222914

\section{Holding Institution}

Missouri Botanical Garden, Peter H. Raven Library

\section{Sponsored by}

Missouri Botanical Garden

\section{Copyright \& Reuse}

Copyright Status: Public domain. The BHL considers that this work is no longer under copyright protection.

This document was created from content at the Biodiversity Heritage Library, the world's largest open access digital library for biodiversity literature and archives. Visit BHL at https://www.biodiversitylibrary.org. 